from a Spanish bullfight as much as a game of bean-bag differs from a college football game. There is no bloodshed, nothing repugnant, but plenty of hilarity, and frequently great athletic ability is displayed by men, horses and bulls. On the short horns of the latter are placed large rubber balls. Sometimes the horse manages to kick the bull in the ribs, when he utters a roar of indignation and returns the insult by butting the horse with his rubber buffers. This pleases the risible centers of the happy Portuguese and the bullfight is over.

There is much that pertains to the Orient in the customs and architecture of Portugal, and the many social laws are; undoubtedly only modified conditions that existed when the Moors ruled the peninsula.

The higher classes in Lisbon and Oporto well appreciate the value of educating their daughters, yet conditions are such that the girls must be confined to conventual supervision. In order to maintain this oversight on the young women, yet have them free to enjoy the learning of other countries, they are taught by English and Irish women. The great convent schools of Bom Successo and Salesias, where the girls of the best society are sent, are controlled exclusively by English and Irish sisters.

This naturally brings me to what I shall have to confine myself in this article-educational matters-though I feel no adequate justice can be done to the charming Portuguese people by neglecting to tell of their home life, or of the struggle educated people, including the king, are making for freedom in religious thought.

There exists in Portugal only one educational institution bearing the honor and title of a university. This was founded in Lisbon in 1288 and transferred in 1307 to Coimbre (pronounee, but do not indite, Quimbre). A bull of Gregory XI was issued October, 1376, which authorized the university to give degrees in letters and theology. In 1377 the university was again transferred to Lisbon, but 200 years later removed to its former home, Coimbre, where it has remained. It has been the battleground for science and religion through many a century. In 1836 came the great movement of the reformers and then were established under the direct control of the government the departments of medicine, law and the arts. Gradually it became a school of modern ideas, and has kept well up in the progress of nations.

The university is composed of five faculties: medicine, law, theology, mathematics and physics. This sast faculty has under its control all instruction in the natural sciences and attached to it are excellent botanical and zo logical gardens. The chairs of Greek and Hebrew are under the charge of the theological faculty. The university buildings are massive, handsome and unique in their architectural designs. They should be well studied, for nowhere throughout the world will the traveler find their equal. The library is large, its decorations are rich and immensely valuable, and combine all the Oriental splendor of the Alhambra with the utility of the libraries in St. Mark's, venice.

The course of instruction at the great Portugal university is essentially modern in that it is free from church interference and generously supported by the state. The professors and those foreigners who are invited to talk to the students have the freedom of the air to say what they think. (This in some respects differs from a few of our universities.)

The professors of Coimbre, all Portuguese, are divided into fifty-three lecturers (lentes) and twenty-two associate lecturers (substitutos). The members of the different faculties are designated by their capes and hats, as follows: Medicine, yellow, 18 members; law, red, 21 members; mathematics, blue, 13 members; philosophy, blue and white, 11 members, and theology, white, 9. On all official occasions and at examinations the professors are dressed in their distinctive robes and hats. The students are obliged to wear a uniform of black cloth, composed of short breeches, cape and black nat, of a disgraceful shape and size. For this latter reason the students go bareheaded except on official occasions.

The last statistics show that there are 1,180 students in all departments, divided as follows: Law, 510; mathematics, 130 ; medicine (and pharmacy), 140; and in the natural sciences,
360 , while it will undoubtedly surprise many readers to learn that in the department of theology there are only 40 students.

The course is five years, and the charge for instruction about $\$ 30$ a year, except in medicine, where it is somewhat greater. The minimum age is 16 years, but the average age of the students is about 19 . Women are rarely seen at the university, the woman of eunuchal tendency not yet having arrived at Portugal. One lone woman of mixed inheritance received a degree of philosophy in 1894. She has disappeared. There are few foreigners at the university, unless we class the Brazilians as such. These latter of Portuguese blood, attend in large numbers.

In Oporto there is a school of medicine where instruction is of a high type. No degrees are conferred by this school, applicants having to pass the examination at Coimbre.

William Lee Howard, M.D.

\section{The Physician and the Pharmacopeia.}

New York, Feb. 18, 1906.

T'o the Editor:-I thank you for your courtesy in printing my letter with the above title in your pages (February 17, p. 526). Your answer, however, requires a reply on my part. You say: "We do not believe anyone suggests that we should be limited to Pharmacopeial preparations." And further you make the statement: "Our correspondent, like too many others, has set up a straw man to knock down." Now, I am not given to setting up straw men, and I am not very likely to make absurd statements, when the subject of proprietary remedies is under discussion, as $I$ have studied the question from all sides, in all its phases, and at a time when too many who show now such commendable zeal on the subject were an absolute terra incognita. I could name you a dozen good, but ignorant men, who just did show themselves so narrowminded and so bigoted as to condemn-condemn utterlyevery proprietary and non-Pharmacopeial preparation. But I can do better than that. In THE Journal of the American Medical Association, January 20 (p. 221, col. 1), Dr. Frank G. Wheatley makes the statement that "the time has come when there are no ethical preparations. We should ignore the whole list. If we will confine our prescribing to articles recognized by the national authority, [The Pharmacopeia], we shall confer one of the greatest boons on the public, and incidentally on ourselves, that the annals of medicine record." And on the same page, column 2, Dr. James C. White is reported as saying, that "though in practice fifty years he had never preseribed a single remedy outside of those contained in the Pharmacopeia." (I wonder if he used cocain between 1884 and 1894, as it was only in the latter year that cocain became official, while Koller discovered it in 1884.) So you see, there are men, so ill-informed, so narrow-minded, as to advocate the non-use of any non-Pharmacopeial preparations. And it was against them that my letter was directed. For I fear that through excess of zeal, through misdirected energy, through intemperate statements of ill-informed persons, who are not familiar with the actual needs of the every day practitioner, our entire work, our labor for years, may go for naught.

William J. Robinson, M.D.

\section{Poison Ivy.}

Washington, D. C., March 6, 1906

To the Editor:-In The JounNaL, Jan. 27, 1906, page 301, you quote from the Cincinnati Lancet-Clinic from an article by Dr. E. S. McKee on the subject of poisoning by poison oak or ivy. Is it possible that the work of Pfaff, published in the Journal of Experimental Medicine (1897, vol. ii, No. 2), is not yet known to the profession?

Dr. MeKee "has been poisoned twice by these plants and feels that he knows many times more about the trouble than he possibly could have known had he not had this experience." I have been poisoned about eignty times and feel that I also know something of the condition.

As a result of the work of Pfaff, we know that the irritant substance of Rhus toxicodendron and Rhus venenata is a fixed oil which is soluble in alcohol and which is precipitated by lead subacetate. The oil is similar to cardol, but is probably not 